\title{
Increased Expression of Human 63-kD Heat Shock Protein Gene in Kawasaki Disease Determined by Quantitative Reverse Transcription-Polymerase Chain Reaction
}

\author{
SEIICHIRO TAKESHITA, HIROKO KAWASE, MIKIO YAMAMOTO, TOMOO FUJISAWA. \\ ISAO SEKINE, AND SHIGETAKE YOSHIOKA \\ Department of Pediatrics /S. T., H.K., T.F., I.S., S.Y./ and the Second Department of Biechemistry /.1.Y./. \\ National Defense Medical College. Tokorozawa. Japan
}

\begin{abstract}
To investigate the possible role of heat shock protein (HSP) in the pathogenesis of Kawasaki disease (KD), we determined the expression of 63-kD HSP (P1 protein) gene in the leukocytes from the peripheral blood of 20 patients with KD, 20 patients with various other febrile diseases, and $\mathbf{1 0}$ healthy children using the quantitative reverse transcription-polymerase chain reaction technique. Although a low but constitutive expression of HSP was observed in the control patients and healthy children, the expression of HSP63 mRNA was significantly higher during the acute phase of KD. Because mycobacterial HSP65, a cognate of human HSP63, is a common immunogen in bacterial species, and because the major immunopathologic feature of $\mathrm{KD}$ is reportedly an abnormally activated immune system, it suggests that an increased level of HSP63 gene transcription may be associated with the pathogenesis of KD. (Pediatr Res 35: 179183,1994 )
\end{abstract}

\section{Abbreviations}

HSP, heat shock protein

KD, Kawasaki disease

CAL, coronary artery lesions

RT-PCR, reverse transcription-polymerase chain reaction

$\mathrm{KD}$ is an acute febrile illness of infants and young children that is characterized by multisystem vasculitis (1). CAL develop in approximately 15 to $20 \%$ of KD patients and may lead to myocardial infarction (2). Although the origin of $\mathrm{KD}$ is not known, epidemiologic features suggest it is caused by an infectious agent (3). Immunologic abnormalities during the acute phase of $\mathrm{KD}$ are characterized by marked activation of the immune system, leading to an increase in cytokine production by activated macrophages/monocytes, T cells, and B cells $(4,5)$. Localized erythema at the site of a previous (bacille CalmetteGuérin) inoculation is a relatively specific and early manifestation of KD. Recently, the antibody response to bacille CalmetteGuerrin antigens was demonstrated in the convalescent sera of patients with $\mathrm{KD}$ by the $\operatorname{IgG}$ immunoblotting method (6). A marked increase in the serum antibody level was detected against both the mycobacterial 65-kD HSP (HSP65) and its human

Received June 10, 1993; accepted September 21, 1993.

Correspondence and reprint requests: Seiichiro Takeshita M.D.. c/o Dr. Donna L. Vredevoe, UCLA School of Nursing. 10833 Le Conte Ave., Los Angeles. CA 90024-6918. homologue (HSP63, Pl antigen) using the synthetic peptide enzyme-linked immunoassay (7). This finding suggests that molecules that cross-react with some infectious agents and mycobacterial bacille Calmette-Guerin antigens and with exogenous HSP65 and endogenous HSP63 may contribute to the inflammatory process in KD.

HSP are evolutionarily highly conserved proteins that are expressed in response to stressful stimuli, including heat, oxidative free radicals, and toxic metal ions (8). HSP have several families, but their functions are still obscure. The amino acid sequence of HSP65 and HSP70 shows a strong similarity to a $40-70 \%$ amino acid identity between HSP of human beings and some bacteria (e.g. Mycobacterium tuberculosis or Escherichia coli) $(9,10)$. Human HSP63, a mitochondrial protein designated P1, is the human homologue of bacterial HSP65. Mycobacterial HSP65 is being studied intensively because of its strong immunogenicity as a common antigen of bacteria and because of its possible involvement in the autoimmune response directed against self-epitopes shared by the mycobacterial and human HSP (11-13).

We investigated the expression of the HSP63 gene using the quantitative RT-PCR with $\beta$-actin internal standard in the acute and convalescent phase of KD as compared with both control patients and various diseases and with healthy children.

\section{MATERIALS AND METHODS}

Patients. We evaluated 20 patients with KD. They were hospitalized at the National Defense Medical College Hospital between August 1991 and December 1992. The group comprised 12 males and eight females, aged 5 mo to $6 \mathrm{y}$. All patients met the diagnostic criteria for KD established by the Japanese Kawasaki Disease Research Committee (14). All were scheduled to receive i.v. Ig. Three patients had CAL. Blood was obtained from 20 patients in the acute phase (median days after onset of fever, $5.1 \pm 1.4 \mathrm{~d}$; mean $\pm \mathrm{SD}$ ) before initiating the administration of Ig and aspirin and from 16 of these patients during the convalescent phase of $K D$ as paired samples $(45.0 \pm 8.1 \mathrm{~d})$ (Table 1$)$.

We evaluated 20 patients with other illnesses as febrile controls. Six had acute bronchitis, three had acute pneumonia, three had EBV infection, two had acute urinary tract infection. two had aseptic meningitis, and one patient each had exanthema subitum. scarlet fever, measles, and rubella. Blood was obtained from 20 patients at the acute febrile phase (median days after onset of fever, $4.8 \pm 1.8 \mathrm{~d}$; mean $\pm S D$ ) and from eight of these patients during the convalescent phase as paired samples (13.1 $\pm 2.9 \mathrm{~d})$. Three had acute bronchitis, and one patient each had acute pneumonia. urinary tract infection, EBV infection, aseptic meningitis, and scarlet fever. Blood was obtained from 10 healthy 
TAKESHITA $E T A L$.

Table 1. Characteristics of patients and controls

\begin{tabular}{|c|c|c|c|c|c|}
\hline & \multicolumn{2}{|c|}{$\mathrm{KD}$} & \multicolumn{2}{|c|}{ Control patients } & \multirow[b]{2}{*}{ Healthy children } \\
\hline & Acute & Convalescent & Acute & Convalescent & \\
\hline Number & 20 & 16 & 20 & 8 & 10 \\
\hline Median age (range) & 19 mo (5 mo-6 y) & $21 \mathrm{mo}(6 \mathrm{mo}-6 \mathrm{y})$ & 27 mo $(8$ mo-9 y) & $27 \mathrm{mo}(8 \mathrm{mo}-9 \mathrm{y})$ & 3 y $(10 \mathrm{mo}-5 \mathrm{y})$ \\
\hline Sex (male/female) & $12: 8$ & $9: 7$ & $9: 11$ & $4: 4$ & $5: 5$ \\
\hline $\begin{array}{l}\text { Median days after onset } \\
\text { of fever (range) }\end{array}$ & $5.1 \pm 1.4(3-8 \mathrm{~d})$ & $45.0 \pm 8.1(32-58 \mathrm{~d})$ & $4.8 \pm 1.8(1-9 d)$ & $13.1 \pm 2.9(8-18 \mathrm{~d})$ & \\
\hline
\end{tabular}

children between the ages of 10 mo and 5 y (median, 3 y) after informed consent had been obtained from the parent or guardian.

Quantitative RT-PCR. Peripheral blood mononuclear cells and neutrophils were isolated from heparinized blood by density gradient centrifugation using Mono-Poly Resolving Medium (ICN Biochemicals, Costa Mesa, CA). Total RNA was isolated by acid guanidium thiocyanate-phenol-chloroform method (AGPC protocol) (15). RNA samples thus isolated were then treated with RNase-free DNase 1 (Takara Shuzo Co., Kyoto, Japan) for $1 \mathrm{~h}$ at $37^{\circ} \mathrm{C}$ to remove any possible contaminating genomic DNA. Two pairs of oligonucleotide primers were prepared for human HSP63-specific sequences (sense: 5' ATAATCGCTGAAGATGTTGA 3' map position 818-837; antisense: 5' TGCAAGCCGTTCATTCAGTT 3' map position 1186-1167) and $\beta$-actin-specific sequences (sense: $5^{\prime}$ AACTGGGACGACATGGAGAA $3^{\prime}$ map position 273-292; antisense: 5' ATACCCCTCGTAGATGGGCA 3' map position 548-529). Accuracy of respective 369-bp and 276-bp PCR products has been confirmed by nucleotide sequencing after cloning into plasmid vectors.

Both antisense primers $(5 \mathrm{pmol})$ were annealed to RNA samples in $20 \mathrm{mM}$ Tris- $\mathrm{HCl}, 0.2 \mathrm{mM}$ EDTA, and $50 \mathrm{mM} \mathrm{KCl}$ for $15 \mathrm{~min}$ at $65^{\circ} \mathrm{C}$ and then incubated for cDNA synthesis with 2 units of reverse transcriptase (RAV-2, Takara Shuzo Co.). 0.4 $\mathrm{mM}$ deoxyribonucleoside triphosphate, $50 \mathrm{mM}$ Tris- $\mathrm{HCl}, 5 \mathrm{mM}$ $\mathrm{MgCl}_{2}$, and $50 \mathrm{mM} \mathrm{KCl}$ for $1 \mathrm{~h}$ at $37^{\circ} \mathrm{C}$ in total reaction volume of $15 \mu \mathrm{L}$. PCR was carried out with $2.5 \mu \mathrm{L}$ of cDNA, 1 unit of Taq DNA polymerase (Pharmacia, Uppsala, Sweden), two pairs of primers (20 pmol), $0.2 \mathrm{mM}$ deoxyribonucleoside triphosphate, $50 \mathrm{mM} \mathrm{KCl}, 1.5 \mathrm{mM} \mathrm{MgCl}$, and $10 \mathrm{mM}$ Tris- $\mathrm{HCl}$ and $10 \mu \mathrm{Ci}$ $\left[\alpha-{ }^{32} \mathrm{P}\right]$ deoxycytidine triphosphate (total volume, $50 \mu \mathrm{L}$ ) in a thermal cycler (Program Temp Control System PC-700, ASTEC, Tokyo, Japan). Each PCR cycle included $1 \mathrm{~min}$ of denaturation at $94^{\circ} \mathrm{C}, 2 \mathrm{~min}$ of primer annealing at $54^{\circ} \mathrm{C}$, and $3 \mathrm{~min}$ of extension at $72^{\circ} \mathrm{C}$. PCR products were separated on $4 \%$ polyacrylamide gels, dried after electrophoresis, exposed overnight to x-ray film (Hyperfilm-MP, Amersham, Arlington Heights, IL), and analyzed with a laser densitometer (LKB 2222-020 Ultroscan XL, Pharmacia).

To evaluate the adequacy of quantitative RT-PCR, we used it to study HeLa cells in which the HSP63 and $\beta$-actin mRNA are both abundantly expressed. The PCR products of HSP63 and $\beta$ actin increased linearly within the range of 20-30 PCR cycles (Fig. $1 A$ and $B$ ). The amount of PCR product was proportional to that of template RNA, in the range of 0.001 and $1 \mu \mathrm{g}$ (Fig. $1 C$ and $1 D$ ). Therefore, we used 25 cycles of PCR amplification. The level of $m$ RNA for HSP63 was expressed as the ratio of HSP63 RT-PCR products to $\beta$-actin (HSP63/ $\beta$-actin ratio). The quantitative differences of HSP63 mRNA present in peripheral leukocytes were compared using the ratio.

Statistical analysis. We used the two-tailed $t$ test where appropriate; $p<0.05$ was considered significant.

\section{RESULTS}

The total RNA was extracted from the peripheral leukocytes of patients with $\mathrm{KD}$, patients with other febrile diseases (control patients), and healthy children, and RT-PCR was carried out.
Figure 2 shows the autoradiographic profiles of quantitative RT PCR for representative cases. HSP63 (369 bp) was expressed at much higher levels in patients in the acute phase of KD than in control patients and healthy children. This finding was clarified using the ratio against $\beta$-actin $(276 \mathrm{bp})$ estimated by densitometer. HSP63 was expressed constitutively in healthy children at very low levels.

As shown in Figure 3 , the HSP63/ $\beta$-actin ratio in the acute phase of $K D(0.33 \pm 0.14$; mean $\pm S D)$ was significantly higher than that of the control patients and healthy children $(0.13 \pm$ 0.10 and $0.11 \pm 0.05$, respectively; $p<0.001$ ). Thus, mRNA of HSP63 was expressed to a greater extent by peripheral leukocytes of acute KD than those of other febrile disorders studied. The mean ratio of patients with acute-phase $\mathrm{KD}$ and CAL $(n=3)$ did not differ significantly from that of patients with KD but without CAL. One of the control patients, a 4-y-old girl with infectious mononucleosis caused by EBV, had a high ratio titer $(0.47)$; the ratios of two other patients with this disease were less than $0.15(0.12$ and 0.10$)$. We also observed that the expressions of HSP63 mRNA were low in two patients with recurrent systemic juvenile rheumatoid arthritis (the HSP63/ $\beta$-actin ratio, 0.11 and 0.13 ), one patient with virus-associated hemophagocytic syndrome $(0.10)$, and three patients with anaphylactoid purpura (range, 0.07-0.13).

We compared the expression of HSP63 in the acute versus the convalescent phase of KD (Fig. 4). Samples were obtained from 16 of the patients with KD and from 8 of the control patients during their convalescent phase. The ratios (mean \pm SD) of the convalescent phase were significantly lower than those of the acute phase (acute versus convalescent: KD, $0.35 \pm 0.14$ versus $0.23 \pm 0.13, p<0.01$ : control patients, $0.19 \pm 0.13$ versus 0.13 $\pm 0.06, p<0.05$ ), but the ratios in the convalescent phase of $\mathrm{KD}$ were still elevated. We also observed that the mean ratio $20 \mathrm{~d}$ after the onset of fever in five patients with KD was high $(0.30$ \pm 0.13 ). The ratio was less than 0.20 in two of three samples obtained 3 mo after the onset of KD (data not shown). This finding indicates that a high level of HSP63 gene expression in $\mathrm{KD}$ was maintained for more than $1 \mathrm{mo}$ and then decreased gradually.

\section{DISCUSSION}

We demonstrated that HSP63 mRNA was expressed at a significantly higher level in patients in the acute phase of KD than in the control patients and the healthy children. Although the origin of KD is obscure, Yokota (6) and Yokota et al. (7) recently reported that the anti-HSP65 antibodies in sera from patients with $\mathrm{KD}$ during convalescence reacted with both synthetic peptides of mycobacterial HSP65 and human HSP63 and that peripheral $T$ lymphocytes from patients with $\mathrm{KD}$ were sensitized to recombinant HSP65. This finding suggested that both bacterial HSP65 and human HSP63 play an important role in $\mathrm{KD}$ pathogenesis at the protein level in an autoimmune fashion. Because no firm evidence exists that the expression of HSP63 protein is increased in KD, the direct proof for the central role of HSP63 is still missing. If the increased synthesis of HSP63 protein is induced, it is assumed that intracellular HSP63 (selfHSP) would be processed and presented in the context of MHC class 1 molecule on the cell surface $(11,16)$. 

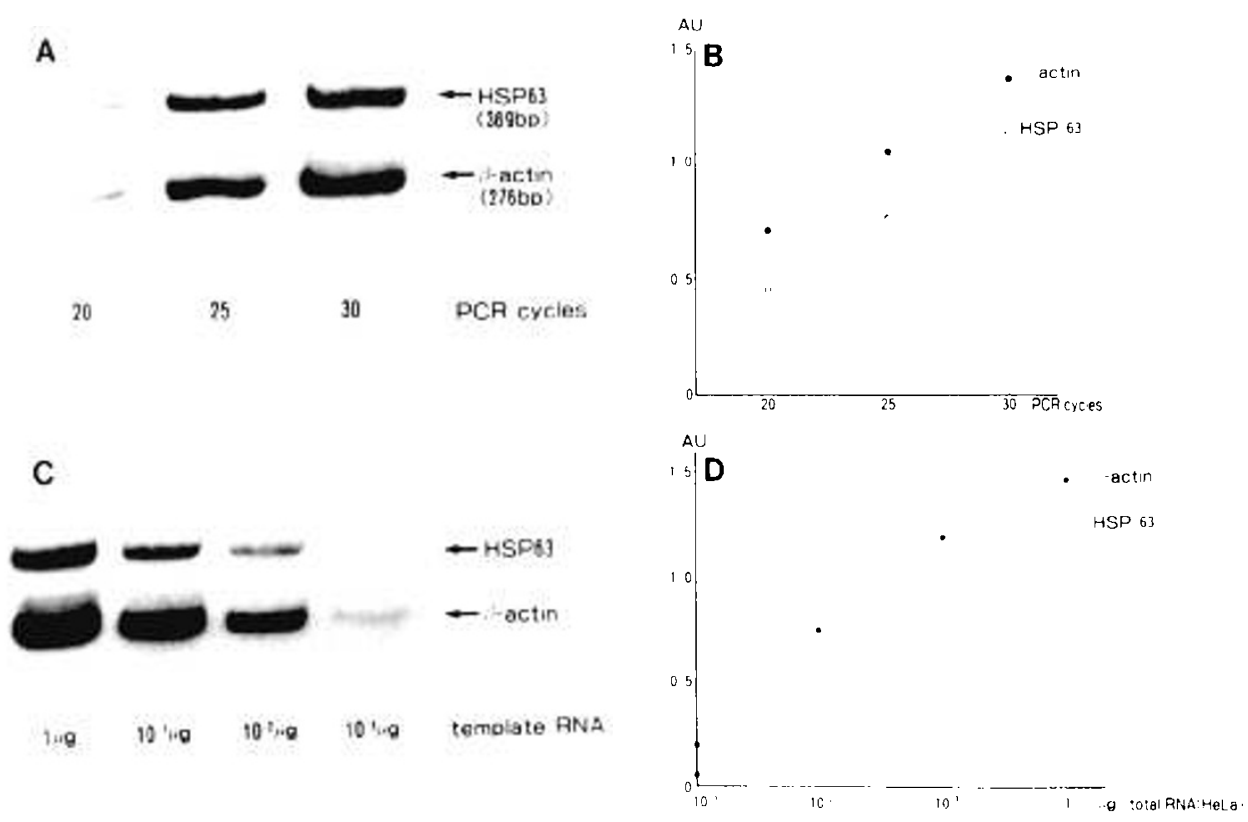

Fig. 1. A, Autoradiogram of the HSP63 and $\beta$-actin PCR products by RT-PCR in HeLa cells. HSP63 mRNA was reverse-transcribed simultaneously with the $\beta$-actin internal standard and amplified in the presence of $\left[\alpha{ }^{-32} \mathrm{P}\right]$ deoxycytidine triphosphate for 20,25 , and 30 cycles. After PAGE, the gel was dried and exposed to x-ray film overnight at room temperature. Arrows indicate the specific product bands for HSP63 (369 bp) and $\beta$-actin $(276 \mathrm{bp})$ sequences. $B$, Absorbance units $(A U)$ of HSP63 and $\beta$-actin increased linearly within $20-30$ PCR cycles. $C$, Autoradiogram of the HSP63 and $\beta$-actin RT-PCR products amplified for 25 cycles in Hela cells RNA $\left(10^{-3}, 10^{-2}, 10^{-1}, 1 \mu \mathrm{g}\right) . D$. Absorbance units of HSP63 and $\beta$ actin increased in proportion to the RNA concentration on a logarithmic scale.

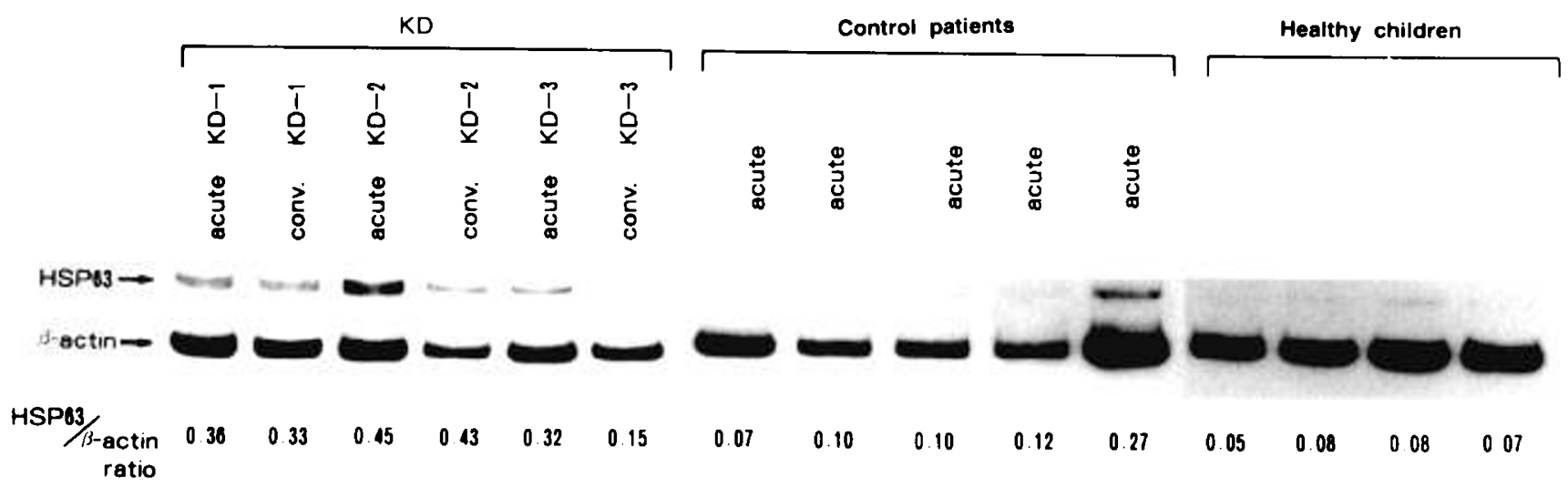

Fig. 2. Autoradiogram of quantitative RT-PCR. Total RNA was extracted from peripheral leukocytes obtained in paired samples (acute and convalescent phase) from three patients with KD, five control patients, and four healthy children, and RT-PCR was carried out. After PAGE and autoradiogram, the expression of HSP63 mRNA was determined as HSP63/ $\beta$-actin ratio with a laser densitometer. The presence of KD was associated with increased expression of the HSP63 gene.

We obtained evidence that the expression of HSP63 increased at $\mathrm{mRNA}$ level in peripheral leukocytes of acute $\mathrm{KD}$ (Figs. 2 and 3 ), indicating that an increase in HSP63 gene expression may not be induced by a rise in temperature (heat shock) but may be relatively specific to the acute phase of $\mathrm{KD}$. We also observed that the expressions of HSP63 mRNA were low in patients with recurrent systemic juvenile rheumatoid arthritis, virus-associated hemophagocytic syndrome, and anaphylactoid purpura. These results suggest that the expression of HSP63 mRNA is not necessarily high in the diseases with a high level of $\mathrm{C}$-reactive protein or with vasculitis.

Previous attempts have been made to quantitate PCR amplification of mRNA with an internal standard such as $\beta$-actin or $\beta_{2}$-microglobulin $(17,18)$. We analyzed HSP63 gene expression quantitatively with the relatively invariant $\beta$-actin mRNA as internal standard. Although it is difficult to measure the absolute amount of HSP63 mRNA, one can compare quantitatively the relative amounts of HSP63 mRNA present in peripheral leukocytes using the HSP63/ $\beta$-actin ratio. However, this approach is semiquantitative and provides only comparative data. The PCR technique must be carefully performed to find the proper concentration for the primers $\mathrm{Mg}^{2+}$ and deoxyribonucleoside triphosphate and to find the optimal PCR cycles because small differences in efficiency could lead to large differences in the amount of PCR product as a result of its sensitivity. The $\left[\alpha-{ }^{32} \mathrm{P}\right]$ deoxycytidine triphosphate-labeled PCR was highly sensitive because the low-level expression of HSP63 as seen in healthy controls barely stained with ethidium bromide after 20-30 PCR cycles.

HSP65, which belongs to the HSP60 family, has important physiologic functions, including protein folding. unfolding, and translocation (16). It has been identified as a major antigen in a variety of bacterial pathogens. HSP63 (mitochondrial protein, P1 antigen) is the human homologue of HSP65; it shares about $65 \%$ of the protein sequence homology with the HSP65 of $M$. tuberculosis (3). A possible role of HSP65 in autoimmunity is suggested by several findings: $I$ ) the presence of $\mathrm{T}$ cells and antibodies against the epitopes shared by bacterial and human 


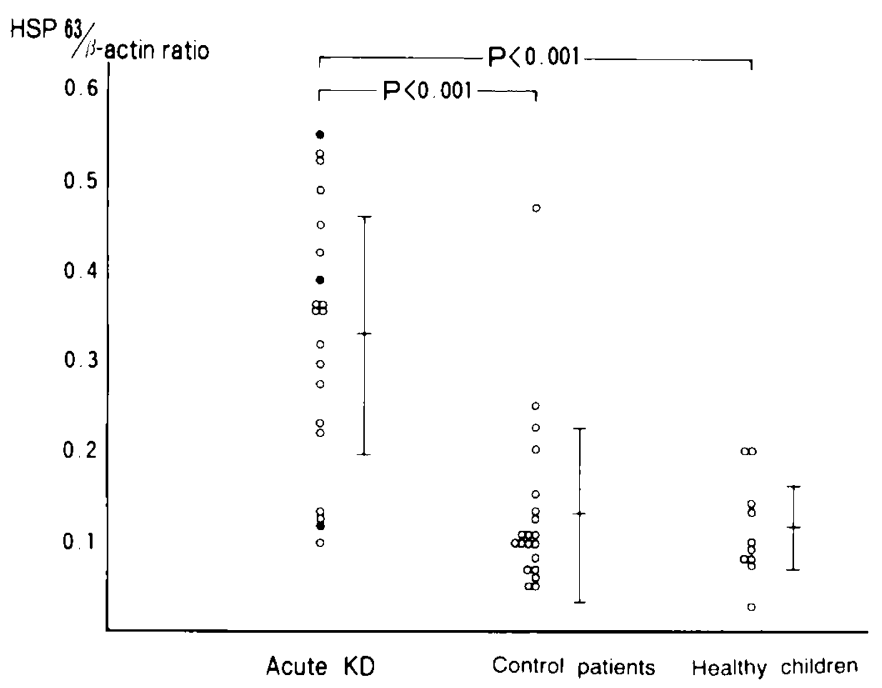

Fig. 3. Expression of HSP63 gene in peripheral leukocytes from patients in the acute phase of KD. control patients, and healthy children. Data are the ratio of the amount of labeled PCR products (HSP $63 / \beta$ actin ratio). The mean HSP63/ $\beta$-actin ratio of patients in the acute phase of $\mathrm{KD}$ was significantly higher than that of control patients and healthy children. Filled circles indicate the three patients with $\mathrm{KD}$ and $\mathrm{CAL}$.

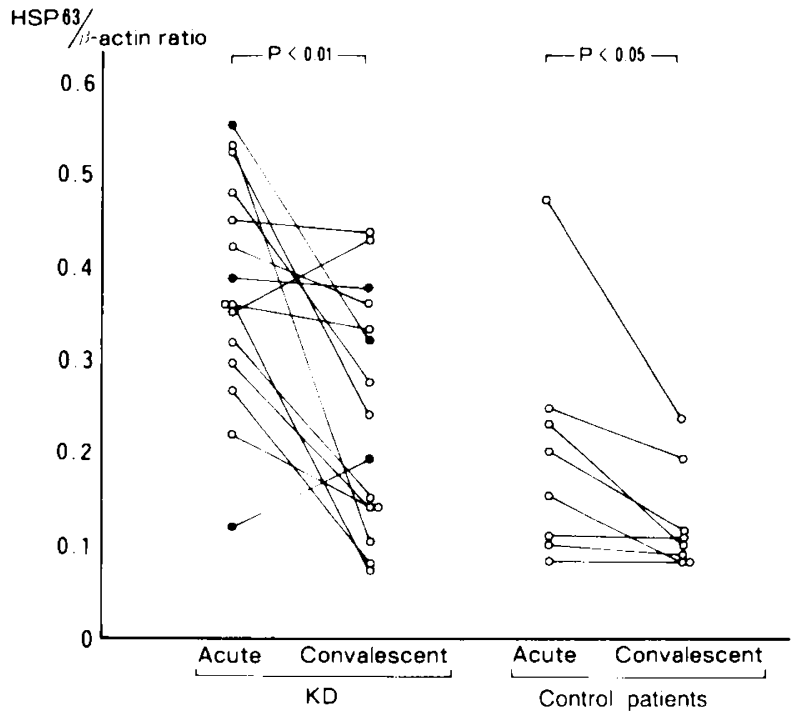

Fig. 4. Expression of HSP63 during the acute and convalescent phase of KD and control patients. The mean HSP63/ $\beta$-actin ratio in the acute phase of KD decreased during the convalescent phase but remained persistently high. Filled circles indicate three patients with KD and CAL.

HSP, 2) the activation of these T cells or antibodies during microbial infection, 3) the expression of self-HSP, and 4) the recognition of these stressed host cells by $T$ cells or antibodies (16). Our finding that the increased expression of self (autologous) HSP is detected in KD is compatible with the autoimmune role of HSP65. HSP65 has also been reported to be a potent immunogen. It induces the production of IL- 1 and tumor necrosis factor (19). HSP65 is a target molecule to cytotoxic T cells $(11,20)$. Therefore, it is suggested that the increased expression of endogenous HSP (HSP63) contributes to the abnormally activated immune system of patients with acute $K D$ via a molecular mimicry between HSP65 and HSP63. The synthesis of HSP has also been reported to be induced by various cytokines, including IL-1, IL-2, interferon, and tumor necrosis factor (21). The mRNA of HSP63 may be consequently transcribed after the increase in cytokine production during the acute phase of $\mathrm{KD}$ and lead to the further production of cytokines. Both findings suggest that HSP63 would presumably be involved in the pathogenesis of $\mathrm{KD}$ as the endogenous stimulus that triggers the immune activation or would have some roles in the cytokine network as an endogenous mediator that affects the host response. In the group of control patients, one of the three patients with EBV infection showed an elevated expression of HSP63 mRNA. This finding may reflect the activation of cytokines because some of the EBV-transformed B cell lines secrete IL-1. IL-6, and tumor necrosis factor (22). This elevation also may be associated with an alteration in mononuclear cell subpopulation.

The observation that the levels of HSP63 mRNA were still elevated in the convalescent phase of KD indicated that the peripheral leukocytes are under stressed conditions during the acute and convalescent phases of this disease. Other factors, such as a suspected infectious agent, rise in body temperature, activation of the cytokine network, and presence of superoxides, can induce the synthesis of HSP63. The transcription factors that regulate HSP63 gene should be studied to explain the influences of these inducers.

In summary, the expression of human HSP63 (self-HSP) was significantly increased in the peripheral leukocytes from patients in the acute phase of KD. An augmented transcription of HSP63 may play an important role in enhancing the immune activation of $\mathrm{KD}$ as endogenous mediator and may thus be involved in the pathogenesis of KD.

\section{REFERENCES}

1. Kawasaki T 1967 Acute febrile mucocutaneous syndrome with lymphoid involvement with specific desquamation of the fingers and toes in children. Clinical observation of 50 cases. Jpn J Allergy 16:178-222

2. Kato H, Koike S, Yamamoto M, Ito Y, Yano E 1975 Coronary aneurysms in infants and young children with acute febrile mucocutaneous lymph node syndrome. J Pediatr 86:892-898

3. Yanagawa H, Nakamura H, Yoshino M, Fujita Y, Nagai N, Kawasaki T, Aso S. Imada Y. Shigematsu I 1988 A nationwide incidence survey of Kawasak disease in 1985-1986 in Japan. J Infect Dis 158:1296-1301

4. Leung DM, Cotran RS, Kurt-Jones E, Burns JC, Newburger JW, Pober JS 1989 Endothelial cell activation and high interleukin-1 secretion in the pathogenesis of acute Kawasaki disease. Lancet 2:1298-1302

5. Furukawa S, Matsubara T, Motohashi T, Tsuda M, Sugimoto H, Yabuta K 1991 Immunological abnormalities in Kawasaki disease with coronary artery lesions. Acta Pedatr Jpn 33:745-751

6. Yokota $S 1991$ Heat shock protein as a predisposing and immunopotentiating factor in Kawasaki disease. Acta Pediatr Jpn 33:756-764

7. Yokota S. Tsubaki K. Kuriyama T, Shimizu H. Ibe M, Mitsuda T, Aihara Y Kosuge K, Nomaguchi H 1993 Presence in Kawasaki disease of antibodies to mycobacterial heat shock protein HSP65 and antibodies to epitopes of human HSP cognate antigen. Clin Immunol Immunopathol 67:163-170

8. Lindquist S, Craig EA 1988 The heat shock protein. Annu Rev Genet 22:631677

9. Hunt C. Morimoto RI 1985 Conserved features of eukaryotic hsp70 genes revealed by comparison with the nucleotide sequences of human hsp70. Proc Natl Acad Sci USA 82:6455-6459

10. Jindal S, Dudani AK, Singh B, Harley CB, Gupta RS 1989 Primary structure of a human mitochondrial protein homologous to the bacterial and plant chaperonins and to the 65-kilodalton mycobacterial antigen. Mol Cell Biol 9:2279-2283

11. Koga T, Wand-Würtenberger A, DeBruyn J, Munk ME, Schoel B, Kaufmann SHE 1989 T cell against a bacterial heat shock protein recognize stressed macrophages. Science 245:1112-1114

12. Munk ME, Shoel B, Modrow S, Karr RW, Young RA, Kaufmann SHE 1989 $T$ lymphocytes from healthy individuals with specificity to self-epitopes shared by the myobacterial and human 65 -kilodalton heat shock protein. J Immunol 143:2844-2849

13. Dudani AK, Gupta RS 1989 Immunological characterization of a human homolog of the 65-kilodalton mycobacterial antigen. Infect Immun 57:27862793

14. Japan Kawasaki Disease Research Committee 1984 Diagnostic Guidelines of Kawasaki Disease, 4th Rev Ed. Japan Kawasaki Disease Research Committee. Tokyo

15. Chomczynski P, Sacchi N 1987 Single step method of RNA isolation by acid guanidium thiocyanate-phenol-chloroform extraction. Anal Biochem 162:156-159

16. Kaufmann SHE 1990 Heat shock protein and immune response. Immunol Today 11:129-136

17. Noonan KE, Beck C, Holzmayer TA, Chin LE, Wunder JS, Andrulis IL 
Gazdar AF, Willman CL, Griffith B, Von Hoff DD, Robinson IB 1990 Quantitative analysis of MDRI (multidrug resistance) gene expression in human tumors by polymerase chain reaction. Proc Natl Acad Sci USA 87:7160-7164

18. Rappoee DA, Mark D, Banda J, Werb Z 1988 Wound macrophages express TGF- $\alpha$ and other growth factors in vivo: analysis by mRNA phenotyping. Science 241:708-712

19. Wallis RS, Amir-Tahmasseb M, Ellner JJ 1990 Induction of interleukin I and tumor necrosis factor by mycobacterial protein. Proc Natl Acad Sci USA $87: 3348-3352$
20. Ottenhoff THM, Ab BK, Van Embden JDA. Thole JER. Kiessling R 1988 The recombinant $65-\mathrm{kD}$ heat shock protein of Micobacterium bovis Bacillus Calmette-Guerin/.11 tuberculosis is a target molecule for $\mathrm{CD}^{+}$cytotoxic $\mathrm{T}$ lymphocytes that lyse human monocytes. J Exp Med 168:1947-1952

21. Polla BS 1988 A role for heat shock proteins in inflammation? Immunol Today 9:134-137

22. Steel CM. Hutchins D 1989 Soluble factors and cell-surface molecules involved in human B lymphocyte activation, growth and differentiation. Biochim Biophys Acta 989:133-151

\section{Announcement}

\section{Annual Meetings}

The American Pediatric Society, The Society for Pediatric Research, and The Ambulatory Pediatric Association will hold their annual meetings May 2-5, 1994 at the Washington State Convention and Trade Center, Seattle. For further information, contact APS/SPR Association Headquarters, 141 Northwest Point Blvd., P.O. Box 675. Elk Grove Village. IL 60009-0675, phone (708) 427-0205, fax (708) 427-1305 or Ambulatory Pediatric Association, 6728 Old McLean Village, McLean, VA 22101, phone (703) 556-9222, fax (703) 556-8729. 